\title{
XII Usteckie Dni Onkologiczne
}

\author{
2-4 października 2015 r.
}

Przewodniczący Komitetu Naukowego:

prof. Piotr Rutkowski - prezes PTChO

prof. Grzegorz Wallner — prezes TChP

Przewodniczący Komitetu Organizacyjnego:

dr Zoran Stojcev

Tematyka:

Przypadki kliniczne - postępowanie w zaawansowanych nowotworach układu pokarmowego

Kontrola po leczeniu radykalnym wybranych nowotworów

Warsztaty diagnostyki i leczenia raka żołądka

Sesja dla pielęgniarek: Główne aspekty opieki pooperacyjnej w chirurgii onkologicznej

Miejsce obrad:

Hotel Royal Baltic w Ustce

Szczegółowe informacje: www.onko.ustka.pl

również na temat propozycji zorganizowania „Dni" w 2016 r. w Macedonii

\section{Konferencja „Biomarkery w chorobach nowotworowych”}

\author{
9-10 października $2015 \mathrm{r}$. \\ Przewodniczący Komitetu Naukowego: \\ prof. dr hab. Piotr Ziółkowski \\ prof. dr hab. Piotr Dzięgiel \\ Organizatorzy: \\ Katedra i Zakład Patomorfologii
}

Katedra i Zakład Histologii i Embriologii Uniwersytetu Medycznego we Wrocławiu

Polskie Towarzystwo Patologów

Polskie Towarzystwo Histochemików i Cytochemików

Tematyka:

biomarkery w diagnozowaniu nowotworów złośliwych oraz ich zastosowanie w celach prognostycznych i w ocenie predykcyjnej

Miejsce obrad:

Wydział Farmaceutyczny z Oddziałem Analityki Medycznej

Uniwersytet Medyczny im. Piastów Śląskich we Wrocławiu

Informacje: www.dolpat.pl

http://dolpat.pl/biomarkery/ 


\title{
II Warszawska Konferencja Onkologiczna
}

27 listopada 2015 r.

Przewodniczący Komitetu Naukowego:

prof. Jacek Fijuth i prof. Edward Towpik

Miejsce

Sala Lustrzana Pałacu Staszica w Warszawie

współorganizator: Via Medica

informacje: www.wko.viamedica.pl

\section{Konferencja Naukowa czasopisma Nowotwory Journal of Oncology} "Debaty Onkologiczne"

8-9 kwietnia 2016 r.

Przewodniczący Komitetu Naukowego

prof. Jacek Jassem i prof. Edward Towpik

Miejsce obrad:

Courtyard by Marriott Warsaw Airport Hotel, ul. Żwirki i Wigury 1, Warszawa

Szczegółowe informacje oraz rejestracja wkrótce na stronie:

www.nowotworykonf.viamedica.pl

\section{Kongres \\ European Society of Surgical Oncology \\ „ESSO 36" \\ 14-16 września 2016 r. \\ i bezpośrednio po nim \\ XXII Zjazd \\ Polskiego Towarzystwa Chirurgii Onkologicznej}

\author{
16-17 września 2016 r. \\ oba zjazdy odbędą się \\ w nowym centrum kongresowym ICE Kraków \\ vis-a-vis Wawelu \\ informacje wkrótce na: \\ www.ptcho.org.pl \\ www.essoweb.org \\ www.zjazd ptcho.org.pl
}




\section{Kongres Onkologii Polskiej}

12-15 października 2016 r.

Miejsce obrad:

Hotel Double Tree by Hilton, ul. Łąkowa 29, Łódź

organizator: Via Medica

informacje - w kolejnych zeszytach Nowotworów 